\title{
KRYZYS DEMOKRACJI NA WSCHODZIE? FREKWENCJA WYBORCZA W NOWYCH KRAJACH ZWIAZZKOWYCH RFN 25 LAT PO ZJEDNOCZENIU
}

\author{
CRISIS OF DEMOCRACY IN THE EAST? \\ VOTER TURNOUT IN THE NEW FEDERAL STATES \\ OF GERMANY 25 YEARS AFTER THE REUNIFICATION
}

Krzysztof Koźbiał*

\begin{abstract}
- ABSTRAKT
$\longrightarrow$

Zarówno w wyborach do Bundestagu, jak i parlamentów krajów związkowych, frekwencja na wschodzie Niemiec jest niższa niż na zachodzie. Jest to jedna z pochodnych innego rozwoju tej części państwa (obszar byłej NRD), a zarazem dowód na „niedokończone zjednoczenie”. W artykule porównano frekwencję wyborczą w obu częściach RFN, próbując nakreślić przyczyny rozbieżności.

Mimo upływu lat różnice w poziomie frekwencji są widoczne. Należy to wiązać z innym wzorem zachowań politycznych na obszarze byłej NRD, innym postrzeganiem roli państwa w demokracji, demograficznymi następstwami zjednoczenia, jak i wyższym poziomem bezrobocia. Z kolei rozbieżności nie są zauważalne w wyborach do Parlamentu Europejskiego, co należy tłumaczyć mniejszym zainteresowaniem wyborców dla tego rodzaju elekcji.
\end{abstract}

In the elections to the Bundestag and the parliaments of federal states the inhabitants of the socalled new federal states of Germany participate noticeably less frequently than people in Western lands. This is demonstrated by the analysis of the turnout in the elections that took place after the reunification of Germany. The differences are not visible only in case of the elections to the European Parliament, but these are of a specific character.

The reasons for this are varied. They include different understanding of democracy, not fully developed civil society, a low level of trust in political parties, the outflow of population from the east and a higher level of unemployment there. In the author's opinion, due to the lack of prospects for changes of these factors, the level of turnout in eastern Germany will probably not increase in the future.

* Państwowa Wyższa Szkoła Zawodowa im. rtm. W. Pileckiego w Oświęcimiu, Instytut Nauk Politycznych. 
Słowa kluczowe: Niemcy, była NRD, frekwencja wyborcza, nowe kraje związkowe, demokracja
Keywords: Germany, former GDR, voter turnout, new federal states of Germany, democracy

W 2015 roku mija 25 lat od zjednoczenia Niemiec. Mimo upływu ćwierć wieku tak zwane nowe kraje związkowe (obszar byłej Niemieckiej Republiki Demokratycznej) pod wieloma względami odbiegają od „starych krajów związkowych” Niemiec. Jedną z płaszczyzn, na której możemy zaobserwować to zjawisko, jest frekwencja wyborcza. Na obszarze byłej NRD kształtuje się ona o kilka punktów procentowych niżej niż na zachodzie Niwemiec.

Artykuł ma na celu porównanie frekwencji wyborczej na wschodzie i zachodzie Niemiec w wyborach do Bundestagu, parlamentów krajowych oraz do Parlamentu Europejskiego. Celem rozważań jest też próba odpowiedzi na pytanie o powód zauważalnych różnic. Analizując dane dotyczące udziału w wymienionych elekcjach, nie brałem pod uwagę jedynie Berlina, ze względu na jego specyfikę jako stolicy, jak i kraju związkowego, w skład którego wszedł także Berlin Zachodni. Podstawą analizy były wyniki wyborów z lat 1990-2015 oraz badania opinii publicznej prowadzone w tym okresie.

Hipoteza autora sprowadza się do stwierdzenia, iż okres 25 lat po zjednoczeniu okazał się dla wschodnich krajów związkowych zbyt krótki, aby wykształciło się przekonanie o ważności mechanizmów demokratycznych, o wadze głosu wyborczego. Frekwencja wyborcza na obszarze byłej NRD jest niższa niż na zachodzie Niemiec. Przyczyny tego zjawiska są zróżnicowane. Zachowania wyborcze obywateli wschodu RFN są zbliżone raczej do zachowań społeczeństw państw postkomunistycznych niż do zachodniej części Niemiec.

\section{ZNACZENIE POZIOMU FREKWENCJI WYBORCZEJ A PROCES ZJEDNOCZENIA NIEMIEC}

Wysoki poziom frekwencji w wyborach (na każdym poziomie) uznawany jest za istotny czynnik legitymizacji systemu demokratycznego. Jak zauważa R. Dahl, demokracja oznacza przede wszystkim bezpośredni udział w wyborach, które są, jeśli nie najważniejszą, to jedną z najważniejszych procedur demokracji jako takiej (1995, s. 316). Znaczenie uczestnictwa w demokratycznych procedurach podkreślają także inni badacze, m.in. G. Sartori (1998, s. 148) (aktywne włączanie 
się w procesy demokratyczne) czy S. Lipset (1998, s. 231) (brak uczestnictwa $\mathrm{w}$ wyborach to brak istnienia społeczeństwa obywatelskiego).

Spadek frekwencji w wyborach jest najczęściej przyczyną pogłębionych analiz dla politologów, ale również przedstawicieli innych nauk. Ich wyniki odnoszą się do prób wyjaśnienia danego stanu rzeczy. Przyczyny te są najczęściej złożone. Mogą odnosić się do problemów związanych z codzienną ludzką egzystencją, poczucia braku perspektyw, ogólnego zniechęcenia, wreszcie poczucia wyobcowania $\mathrm{z}$ systemu politycznego przejawiającego się np. przekonaniem o nieistotności wpływu jednostki na proces decydowania o sprawach ogółu.

Zjednoczenie Niemiec - polegające na połączeniu dwóch różnych organizmów gospodarczych, politycznych oraz społecznych - było pewnego rodzaju eksperymentem. Poprzez ponad 40 lat wschodnia część Niemiec (dawna NRD) pozbawiona była demokracji, a istniejące instytucje polityczne miały w praktyce do spełnienia rolę fasadową, mającą legitymizować „demokrację ludową”. Po włączeniu NRD do RFN społeczeństwo wschodnioniemieckie z dnia na dzień musiało „nauczyć się demokracji”. W pierwszych po zjednoczeniu wyborach do niemieckiego parlamentu wzięło udział 77,8\% uprawnionych do głosowania, czyli 6,5 punktu procentowego mniej niż trzy lata wcześniej. Spadek frekwencji był zatem zauważalny. Do tego zjawiska przyczynili się także wyborcy ze wschodu Niemiec, których udział w głosowaniu był niższy niż na zachodzie.

Mimo upływu 25 lat pod wieloma względami proces zjednoczenia państwa niemieckiego trudno uznać za zakończony. Jedną z płaszczyzn pokazujących ewidentne różnice między „Ossis” a „Wessis” jest właśnie udział w wyborach. $\mathrm{Na}$ wschodzie Niemiec wykształcił się inny wzór zachowań politycznych niż na zachodzie, charakteryzujący się z jednej strony niższą frekwencją wyborczą, a $\mathrm{z}$ drugiej poparciem dla postkomunistycznej partii PDS, obecnie Die Linke, nastawionej sceptycznie wobec podstaw systemu politycznego Niemiec (Abold, Steinbrecher, 2007, s. 143).

Twierdzenie o innym wzorcu zachowań politycznych oraz odmiennym podejściu do systemu demokratycznego potwierdzają badania opinii publicznej. Mimo długoletnich doświadczeń życia w państwie autorytarnym na wschodzie w 2002 r. jedynie 68\% odrzucało możliwość funkcjonowania dyktatury, na zachodzie $88 \%$. Pozytywne nastawienie do gospodarki reprezentowało 54\% pytanych, na zachodzie 75\%. Pozytywną ocenę demokracji jako idei, na której powinno zostać oparte funkcjonowanie państwa, wyraziło odpowiednio 70 i $84 \%$ ankietowanych (Abold, Steinbrecher, 2007, s. 143). W 2005 r. 85\% pytanych 
na zachodzie uznało, że demokracja to najlepsza forma rządów, na wschodzie zgodziło się z tym 64\% (http://www.bpb.de..., 26.05.2015).

Zauważalny jest większy sceptycyzm obywateli landów wschodnich wobec demokracji i określeń wywołujących z nią skojarzenia. W następstwie tych różnic podział wschód-zachód stał się w praktyce kolejną linią podziału w systemie politycznym RFN. Przeczy to tezie o pełnej jedności wewnętrznej. Niektórzy z badaczy dowodzą jednak, iż mamy do czynienia z różnicami o charakterze regionalnym, niewynikającymi z procesu łączenia obu państw niemieckich (Veen, 1997, s. 19-28). Trudno zgodzić się z tą opinią.

Dostrzegalne było także rozczarowanie procesem zjednoczenia, z którym wiązano nadzieję na szybkie wyrównanie warunków życia. Pierwsza tak zwana faza euforii nie była pozbawiona uprzedzeń odnoszących się m. in. do tworzenia obrazu mieszkańców nowych krajów związkowych jako niezdolnych do demokracji, a także do powstania stereotypu „Besserwessi” - „lepszych” mieszkańców zachodniej części Niemiec. W 1990 r. 61\% obywateli „nowych landów” określało się raczej jako „Niemcy” niż „wschodni Niemcy”. Cztery lata później już tylko 35\% (http://www.mz-web.de..., 26.05.2015). Pod koniec lat 90.3/4 mieszkańców wschodniej części RFN uważało, że ze zjednoczenia profity czerpią głównie obywatele zachodniej części kraju. Jednak w zachodniej części 83\% wyrażało pogląd, iż jest dokładnie odwrotnie (Simon, 2004, s. 26-31). Stereotypy tego rodzaju utrzymują się także obecnie. Portale internetowe publikują zarówno dowcipy na ten temat oraz wykazy najczęściej używanych stereotypów (Tag der..., 26.05.2015).

Fakt, iż proces zjednoczenia trudno uznać za udany pod każdym względem, potwierdzają także liczne analizy. W maju 2015 r. tygodnik Focus opublikował porównanie (porównano 402 regiony: powiaty i miasta na prawach powiatu) mające odpowiedzieć na pytanie, gdzie w Niemczech żyje się najlepiej (Deutschlands..., s. 60-75). Biorąc pod uwagę 12 parametrów (m.in.: wzrost gospodarczy, zatrudnienie, produktywność, podatki, dochody, trendy migracyjne), wniosek jest jednoznaczny: regiony położone na wschodzie Niemiec pozostają daleko w tyle za regionami zachodnimi. Najwyżej z obszaru dawnej NRD oceniono położony na południe od Berlina powiat Teltow-Fläming (140 miejsce), podczas gdy sam Berlin znalazł się dopiero na 198 miejscu. Inne najlepiej rozwinięte powiaty w poszczególnych landach wschodnich to: w Meklemburgii-Pomorzu Przednim Landkreis Rostock (270 miejsce), w Saksonii Lipsk (224), w Saksonii-Anhalt Saale Kreis (268), w Turyngii Weimarer Land (291). 
Negatywnymi skutkami zjednoczenia stały się deindustrializacja i odpływ siły roboczej oraz emigracja ludności na zachód. Tylko w okresie pierwszego dziesięciolecia po zjednoczeniu obszar nowych landów opuściło 3,3 mln ludzi, z czego 2,9 mln osiedliło się w landach zachodnich (Simon, 2004, s. 34). Emigracja to dokonywała się falami a jej największe natężenie przypadło na pierwsze lata po zjednoczeniu (szerzej: Dienel, 2004, s. 93-110). Ponad 60\% wyjeżdżających miało poniżej 30 lat, co także (jak można domniemywać) mogło przełożyć się na niższą frekwencję wyborczą.

Autorzy z Uniwersytetu w Aberdeen, analizujący procesy wyborcze w nowych demokracjach europejskich po upadku systemu komunistycznego, zwrócili uwagę na okres między zmianą systemu rządów na demokratyczny (wzięli pod uwagę także Niemcy po upadku nazizmu, Włochy po obaleniu władzy faszystowskiej, Grecję po obaleniu rządów junty wojskowej, a także autorytarne reżimy na płw. Iberyjskim) a wejściem do Unii Europejskiej. Na tym tle państwa środkowej części Starego Kontynentu wypadły stosunkowo mało pozytywnie, bowiem między demokratyzacją ich systemów politycznych a wejściem do Unii minęło aż 14 lat, podczas gdy w przypadku Niemiec Zachodnich było to 8, natomiast w przypadku Grecji tylko 7 lat (Rose, Munro, 2009, s. 5-6).

Co zastanawiające, Richard Rose i Neil Munro nie wspomnieli o obszarze byłej Niemieckiej Republiki Demokratycznej, która od razu została „rzucona na głęboką wodę”, poddana procesowi przyspieszonej transformacji ustrojowej, gospodarczej i społecznej. W konsekwencji obszar ten obecnie pod wieloma względami odróżnia się do zachodniej części zjednoczonych Niemiec.

\section{POZIOM FREKWENCJI WYBORCZEJ W "NOWYCH” KRAJACH ZWIAZZKOWYCH RFN}

W analizie wziąłem pod uwagę trzy rodzaje elekcji. Pozwala to na odpowiedź na pytanie o występowanie (bądź nie) różnic. Regułą jest niższa frekwencja wyborców w nowych krajach związkowych RFN. Zjawisko w pełni nie uzewnętrzniło się jedynie w wyborach do Parlamentu Europejskiego.

Frekwencję w wyborach do Bundestagu, które po zjednoczeniu państw niemieckich odbyły się siedmiokrotnie, przedstawiono w tabeli 1, porównując ogólną frekwencję na obszarze całego państwa oraz w poszczególnych „nowych” krajach związkowych. 
Tabela 1. Frekwencja w wyborach do Bundestagu na obszarze całych Niemiec i w poszczególnych wschodnich krajach związkowych od 1990 r. (w procentach)

\begin{tabular}{|c|c|c|c|c|c|c|}
\hline $\begin{array}{c}\text { Rok } \\
\text { wyborów }\end{array}$ & NIEMCY & Brandenburgia & $\begin{array}{c}\text { Meklemburgia } \\
\text { Pomorze } \\
\text { Przednie }\end{array}$ & Saksonia & $\begin{array}{c}\text { Saksonia } \\
\text { Anhalt }\end{array}$ & Turyngia \\
\hline 1990 & $\mathbf{7 7 , 8}$ & 73,8 & 70,9 & 76,2 & 72,2 & 76,4 \\
\hline 1994 & $\mathbf{7 9 , 0}$ & 71,5 & 72,8 & 72,0 & 70,4 & 74,9 \\
\hline 1998 & $\mathbf{8 2 , 2}$ & 78,1 & 79,4 & 81,6 & 77,1 & 82,3 \\
\hline 2002 & $\mathbf{7 9 , 1}$ & 73,7 & 70,6 & 73,7 & 68,8 & 74,8 \\
\hline 2005 & $\mathbf{7 7 , 7}$ & 74,9 & 71,2 & 75,7 & 71,0 & 75,5 \\
\hline 2009 & $\mathbf{7 0 , 8}$ & 67,0 & 63,0 & 65,0 & 60,5 & 65,2 \\
\hline 2013 & $\mathbf{7 1 , 5}$ & 68,4 & 65,3 & 69,5 & 62,1 & 68,2 \\
\hline
\end{tabular}

Źródło: Ergebnisse (2015), s. 8-9.

Dane jednoznacznie wskazują, iż w okresie od 1990 r. udział w wyborach na wschodzie Niemiec był niższy niż w całym kraju. Różnica wynosiła z reguły kilka punktów procentowych na niekorzyść wschodnich landów. Tylko w jednym przypadku (w Turyngii w 1998 roku) udział w wyborach był wyższy niż średnio w Niemczech. W każdym z pozostałych przypadków udział ten był niższy. Różnice wahały się od -1,4 punktu procentowego (1990 r., Turyngia) do -10,3 punktu procentowego (Saksonia-Anhalt w 2002 i 2009 r.). Warto dodać, iż wschodnimi landami, w których udział w wyborach najmniej odbiegał od średniej, są Turyngia i Saksonia. Na przeciwnym biegunie znajdują się Saksonia-Anhalt i Meklemburgia-Pomorze Przednie. Różnice we frekwencji między wschodnimi i zachodnimi krajami związkowymi przedstawiono na wykresie 1.

Zróżnicowanie jest zjawiskiem stałym. Odsetek biorących udział w wyborach do parlamentu niemieckiego waha się w obu częściach analizowanego państwa. Najmniejsza rozbieżność wystąpiła w 1998 r. (-2,8 punktu procentowego), największa podczas elekcji z 1994 r. (-7,9 p. p.), z kolei podczas ostatnich wyborów zmniejszyła się do $-4,8$ punktów procentowych. Dane te przybliżono na wykresie 2. W oparciu o nie uzasadnione wydaje się stwierdzenie o występującym zróżnicowaniu, które nie ma jednak określonego charakteru. Raz różnice te zwiększają się, innym razem zmniejszają się. 


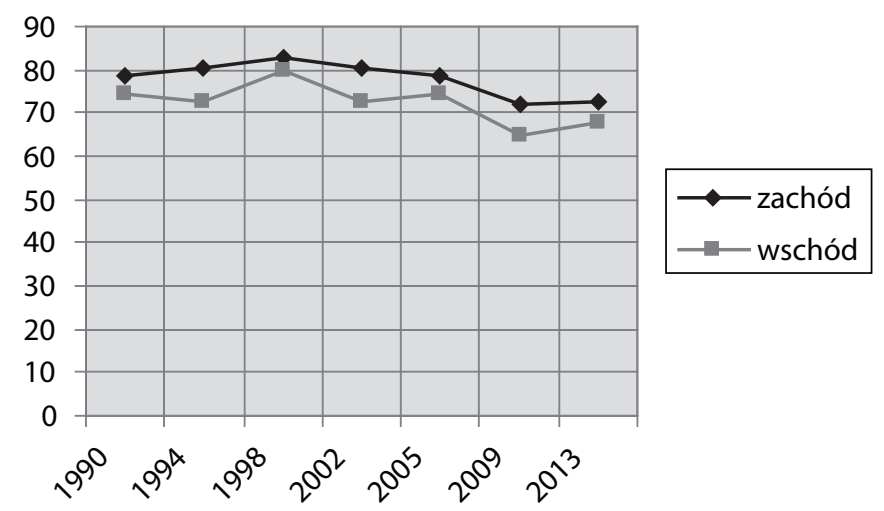

Wykres 1. Frekwencja w wyborach do Bundestagu we wschodnich i zachodnich krajach związkowych Niemiec od 1990 r.

Źródło: Ergebnisse (2014), s. 18.

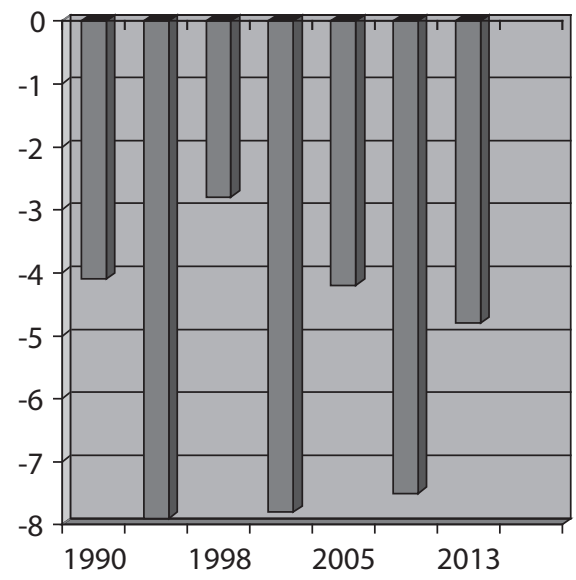

wschodnie kraje związkowe RFN

Wykres 2. Różnica frekwencji we wschodnich krajach związkowych w stosunku do zachodnich krajów związkowych w wyborach do Bundestagu w latach 1990-2013 (w punktach procentowych)

Źródło: obliczenia własne. 
Drugim obszarem analizy są wybory do parlamentów krajów związkowych. Specyfika ustroju RFN powoduje, iż odbywają się one w różnym terminie, różna jest także kadencja wybieranych parlamentów. Także podczas tych wyborów daje się zauważyć ogólnoniemiecka tendencja do coraz mniejszego w nich uczestnictwa, co następowało w zwolnionym tempie do 2006 r. i przyspieszyło po tej właśnie dacie (Eisel).

Próg 70\% uczestnictwa w elekcjach we wschodnich landach przekraczany był stosunkowo rzadko. W 1998 r. w Meklemburgii-Pomorzu Przednim w wyborach na szczeblu kraju związkowego wzięło udział 79,4\% uprawnionych do wyboru, w 1994 r. w Turyngii głosowało 74,8\%, w Saksonii w 1990 r. 72,8\%. Odtąd notuje się tendencję spadkową (w wyborach z 2014 r. tylko 49,1\% głosujących). Najniższą frekwencję zanotowano w Saksonii-Anhalt w 2006 r. (jedynie 44,4\%) (Ergebnisse, 2015).

Gdyby brać pod uwagę frekwencję podczas pierwszych po zjednoczeniu i ostatnich wyborów do landtagów w pięciu wschodnich krajach związkowych, można wówczas zaobserwować duży spadek głosujących. Różnice wynoszą od $-13,3$ punktów procentowych w przypadku Meklemburgii-Pomorza Przedniego do aż $-23,6$ p. p. w Saksonii (sic!). Zainteresowanie wyborców tymi elekcjami obniżyło się zatem znacznie bardziej niż w przypadku wyborów do niemieckiego parlamentu.

Spadek udziału w wyborach na szczeblu krajów związkowych występuje także na zachodzie kraju, lecz nie przybrał on aż takich rozmiarów (różnice między początkiem lat 90. a ostatnimi wyborami to $\mathrm{z}$ reguły kilka punktów procentowych). Wyjątek stanowią Brema (różnica między głosowaniami z 1991 i 2015 r. to $-22,1$ p. p.) oraz Kraj Saary (między 1990 a 2012 r. spadek liczby głosujących to $-21,6$ p. p.).

W konsekwencji można mówić o tzw. rozwieraniu się nożyc w głosowaniu na szczeblu landów. Zjawisko to polega na tym, że zwiększa się różnica między głosującymi w starych i nowych krajach związkowych. O ile w latach 90. i na początku XXI w. średnia różnica we frekwencji wynosiła kilka punktów procentowych, o tyle obecnie zwiększyła się do kilkunastu punktów procentowych. Aktualnie trudno ustalić, czy jest to zjawisko o charakterze stałym, czy też nie. Udział w ostatnich wyborach do parlamentów krajów związkowych na obszarze RFN przedstawiono $\mathrm{w}$ tabeli 2. 
Tabela 2. Frekwencja w ostatnich wyborach do parlamentów krajowych w RFN, stan na 1 września 2015 r.

\begin{tabular}{|c|c|c|c|c|c|}
\hline Kraj związkowy & $\begin{array}{c}\text { Rok } \\
\text { wyborów }\end{array}$ & Frekwencja & Kraj związkowy & $\begin{array}{c}\text { Rok } \\
\text { wyborów }\end{array}$ & Frekwencja \\
\hline $\begin{array}{c}\text { BADENIA- } \\
\text {-WIRTEMBERGIA }\end{array}$ & 2011 & 66,3 & KRAJ SAARY & 2012 & 61,6 \\
\hline BAWARIA & 2013 & 63,6 & $\begin{array}{l}\text { MEKLEMBUR- } \\
\text { GIA-POMORZE } \\
\text { PRZEDNIE }\end{array}$ & 2011 & 51,5 \\
\hline BERLIN & 2011 & 60,2 & $\begin{array}{c}\text { NADRENIA-PALLA- } \\
\text { TYNAT }\end{array}$ & 2011 & 61,8 \\
\hline BRANDENBURGIA & 2014 & 47,9 & $\begin{array}{c}\text { NADRENIA-PŁN. } \\
\text { WESTFALIA }\end{array}$ & 2012 & 59,6 \\
\hline BREMA & 2015 & 50,1 & SAKSONIA & 2014 & 49,1 \\
\hline DOLNA SAKSONIA & 2013 & 59,4 & $\begin{array}{l}\text { SAKSONIA- } \\
\text {-ANHALT }\end{array}$ & 2011 & 51,2 \\
\hline HAMBURG & 2015 & 56,5 & $\begin{array}{l}\text { SZLEZWIK- } \\
\text {-HOLSZTYN }\end{array}$ & 2012 & 60,2 \\
\hline HESJA & 2013 & 73,2 & TURYNGIA & 2014 & 52,7 \\
\hline
\end{tabular}

Źródło: Opracowanie własne na podstawie: www.bundeswahlleiter.de.

Mimo spadku udziału w wyborach do krajowych landtagów uzasadniona wydaje się teza, iż elekcje te można „pod względem ważności” nieoficjalnie lokować zaraz po wyborach do Bundestagu.

Trzeci obszar analizy to wybory do Parlamentu Europejskiego, które w Niemczech po zjednoczeniu odbyły się piąty razy. Cechują się one generalnie najmniejszym zainteresowaniem niemieckich wyborców, co zresztą jest charakterystyczne nie tylko dla RFN, ale i wszystkich krajów członkowskich Unii Europejskiej (podczas wyborów do Parlamentu Europejskiego w 2014 r. zanotowano najniższą w historii frekwencję: 42,61\%). Analiza frekwencji w tych wyborach zasadniczo nie potwierdza hipotezy o zauważalnie rzadszym udziale mieszkańców wschodnich landów w elekcjach. Poziom tego udziału przedstawiono w tabeli 3.

Frekwencja jest zbliżona w obu częściach RFN, dwukrotnie zdarzyło się nawet, że w nowych krajach związkowych była ona wyższa niż na obszarze całego państwa. W ostatnich wyborach z 2014 r. różnica wynosiła zaledwie 0,6 punktu procentowego. 
Tabela 3. Frekwencja w wyborach do Parlamentu Europejskiego w Niemczech i we wschodnich krajach związkowych w latach 1994-2014

(w procentach)

\begin{tabular}{|c|c|c|}
\hline $\begin{array}{c}\text { Rok } \\
\text { wyborów }\end{array}$ & Niemcy & $\begin{array}{c}\text { Wschodnie kraje } \\
\text { związkowe }\end{array}$ \\
\hline 1994 & 60,0 & 63,0 \\
\hline 1999 & 45,2 & 47,8 \\
\hline 2004 & 43,0 & 42,2 \\
\hline 2009 & 43,3 & 42,1 \\
\hline 2014 & 48,1 & 47,5 \\
\hline
\end{tabular}

Źródło: Obliczenia własne na podstawie: www.bundeswahlleiter.de

Nie należy jednak zapominać o nieco innym charakterze tych wyborów. Prawie połowa Niemców uznaje, iż są one niewiele znaczące, w konsekwencji pozostają w domach nie głosując (wyniki badania opinii publicznej z kwietnia 2014 r.) (Hälfte..., 27.05.2015).

Parlament Europejski uznawany jest przez niemieckich wyborców za gremium o niewielkim znaczeniu, nie odgrywa istotnej roli fakt, iż przewodzi mu obecnie Niemiec Martin Schulz. Kampania przedwyborcza odnosi się zdecydowanie częściej do problemów niemieckich niż europejskich. W związku z tym niebiorący udziału w tych wyborach jako powód absencji najczęściej wymieniają brak wiedzy o polityce europejskiej niemieckich ugrupowań. W konsekwencji wybory te nierzadko są określane już nawet nie jako drugorzędne, ale wręcz czwartorzędne. Wynika to $\mathrm{z}$ faktu, iż pracę Bundestagu jako bardzo ważną lub ważną ocenia $86 \%$ ankietowanych, landtagów - 80\%, rad gminnych i miejskich - 76\%, a Parlamentu Europejskiego - jedynie 56\% (Neu, 2014, s. 2-5).

W konsekwencji udział w wyborach do Parlamentu Europejskiego jest o ponad 20 punktów procentowych niższy niż w wyborach do niemieckiego parlamentu. Wyborcy zarówno ze wschodnich, jak i zachodnich landów biorą w nich udział w ostatnich latach stosunkowo rzadko, ponad połowa od wyborów w 1999 roku nie głosuje. 


\section{PRZYCZYNY NIŻSZEJ FREKWENCJI}

Odpowiedź na pytanie o powody niższej frekwencji wyborczej we wschodnich krajach związkowych RFN jest złożona i wieloaspektowa. Nie jest możliwe wskazanie jednej, ogólnej przyczyny wyjaśniającej postawioną kwestię. Jest ich kilka, $\mathrm{z}$ reguły utrzymują się one przez cały okres po zjednoczeniu, najczęściej bez widocznych w przyszłości szans na zmianę.

Niegłosujący w wyborach charakteryzują się specyficznymi cechami, opisanymi w naukach społecznych. Należy do nich zaliczyć: status społeczny i ekonomiczny (poziom wykształcenia, wykonywany zawód, dochody), wiek, płeć, wyznanie, stopień społecznego zaangażowania, wreszcie polityczne wyobcowanie i nieinteresowanie się wydarzeniami związanymi z polityką (Kleinheiz, 1995, s. 26-29 zamieniłem na -, 56). Odnosząc owe cechy do Niemiec, zwraca się uwagę na kilka czynników.

Po pierwsze, należy podkreślić nieco inne pojmowanie demokracji jako takiej, które występuje we wschodnich landach Republiki Federalnej Niemiec. Postawy obywateli obu części państwa niemieckiego różnią się pod tym względem. W zachodniej części kraju stopień zadowolenia z demokracji jest istotnie wyższy (od kilku do ponad 20 punktów procentowych) i utrzymuje się przez cały okres po zjednoczeniu. W 2012 r. zadowolenie z demokracji na zachodzie Niemiec wyraziło $68 \%$ pytanych (wynik porównywalny z Francją i Belgią), na wschodzie jedynie 50\% (dla porównania w Polsce 51\%, choć średnia dla Europy Środkowowschodniej wyniosła jedynie 31\%) (Zufriedenheit..., 30.05.2015). Dwa lata później wynik badań z 2014 r. wykazał, iż na zachodzie zadowolenie z demokracji wyraziło 90, a na wschodzie 82\% pytanych) (Deutschland, 2015, s. 23). Nieco mniejsze różnice zarysowują się, jeśli chodzi o stopień zadowolenia z systemu politycznego RFN (84 do 74\% na korzyść zachodniej części kraju (http://de.statista..., 30.05.2015).

Po drugie, na wschodzie Niemiec istnieje nieco inny zespół pojęciowy związany ze słowem „demokracja”. Inaczej jest pojmowana także rola państwa. W tej części RFN częściej niż na zachodzie określa się związek demokracji z lepszą sytuacją gospodarki, kontrolą przedsiębiorstw przez rząd. 4/5 mieszkańców wschodnich landów uznaje, iż zadaniem rządu jest zapewnienie pracy każdej osobie, która chce pracować. $83 \%$ uważa, że zadaniem państwa jest niwelacja różnic w zarobkach, aż $85 \%$ zgadza się ze stwierdzeniem, że ceny powinny być kontrolowane centralnie (Zawilska-Florczuk, Ciechanowicz, 2011, s. 25-26). Uzasadnione wydaje się zatem stwierdzenie o chęci funkcjonowania w państwie 
opiekuńczym, które wyręczy obywatela we wszystkich, bądź prawie wszystkich zadaniach. Ten model państwa byłby zapewne pożądany przez obywateli wschodnich landów. Niemcy ze wschodu generalnie mniej ufają instytucjom życia publicznego niż ich pobratymcy z zachodu (Roland, 2015, s. 16). Nastawienie to jest bezsprzecznie pochodną okresu komunistycznego.

Po trzecie, o sile rozwoju prawdziwej demokracji świadczy rozwój społeczeństwa obywatelskiego, co może przejawiać się aktywnością na wielu polach. Wschodnie kraje związkowe RFN także pod tym względem wykazują niedostateczny rozwój. Udział mieszkańców tej części kraju w działalności społecznej wzrasta, lecz ciągle jest niższy niż na zachodzie. Aktywność społeczeństwa landów wschodnich przejawia się najczęściej w takich dziedzinach jak sport, organizacja czasu wolnego, muzyka, sztuka i kultura. Organizacje związane z szeroko rozumianą polityką pozostają daleko w tyle (szerzej zob.: Gensicke, Olk, Reim, Schmithals, Dienel, 2010; Olk, Gensicke, 2013). Za główną przyczynę takiego stanu uważa się brak wiary w możliwość zmiany otaczającej rzeczywistości poprzez swój aktywny udział. To z kolei tłumaczone jest najczęściej ogólnym zniechęceniem wynikającym z długotrwałego bezrobocia. Nie bez znaczenia jest przy tym okres rządów komunistycznych, w którym zaangażowanie w rozmaite formy „fasadowego" uczestnictwa było obowiązkowe w zasadzie na każdym etapie rozwoju, począwszy od najmłodszych lat (Zawilska-Florczuk, Ciechanowicz, 2011, s. 27-28).

Po czwarte, co należy uznać za cechę charakterystyczną państw postkomunistycznych, dostrzegalną także na obszarze byłej NRD, wyborcy mają bardzo niski poziom zaufania do partii politycznych, w konsekwencji czego niejednokrotnie stanowi to barierę w głosowaniu w ogóle. W badaniach opinii publicznej mieszkańcy państw postkomunistycznych najczęściej jako wybór najpopularniejszy wybierali „partię bez nazwy”, nieokreśloną (Rose, Munro, 2009, s. 34-37). W 2014 r. w skali od 0 do 4 (gdzie 4 oznaczało największy stopień zaufania) na wschodzie zaufanie do instytucji związanych z partiami politycznymi wynosiło 2,0 - niewiele jednak odbiegając od landów zachodnich, lecz w każdej formie zaangażowania w te ugrupowania (począwszy od członkostwa w partii, a skończywszy na podpisywaniu petycji udział na wschodzie był niższy - jedynym wyjątkiem był dialog obywatelski) (Deutschland, 2015, s. 45-47). W konsekwencji osoby niemające zaufania do partii, polityki i polityków powstrzymują się od udziału w akcie wyborczym, uznając absencję wyborczą za rozwiązanie alternatywne (Roth, 2004, s. 180-184; Völkl, 2007, s. 16-32).

Nie może dziwić fakt, iż identyfikacja $z$ ugrupowaniami politycznymi na zachodzie Niemiec jest zauważalnie wyższa. Po zjednoczeniu obywatele byłej 
NRD mogli wybierać w ofercie wyborczej partii już ukształtowanych w okresie istnienia państwa zachodnioniemieckiego. Jedynie ugrupowanie postkomunistyczne, otrzymujące zresztą największe poparcie na wschodzie, mogło być postrzegane przez tę część wyborców jako atrakcyjne (szerzej zob.: Neller, Thaidigsmann, 2007, s. 189-206).

Po piąte, bez wątpienia za czynnik mający ważny wpływ na absencję wyborczą należy uznać zjawisko bezrobocia, w wielu przypadkach bezrobocia długotrwałego. Według Federalnego Urzędu Pracy w kwietniu 2015 r. stopa bezrobocia na obszarze landów wschodnich wynosiła 9,5\%, podczas gdy na zachodzie jedynie $5,8 \%$ (http://statistik..., 30.05.2015). Nie należy przy tym zapominać, iż w całym okresie po zjednoczeniu różnice te były jeszcze wyższe. We wschodnich krajach związkowych na początku XXI w. bezrobocie przekraczało 20\%. Jak dowodzi Thorsten Faas, wpływ bezrobocia na absencję wyborczą jest czynnikiem istotnym. Bycie bezrobotnym zwiększa możliwość absencji w wyborach w zasadzie na każdym szczeblu. Jedynym zanotowanym przez wspomnianego autora przypadkiem odmiennym były wybory do Bundestagu w 1994 roku, co należałoby uznać raczej za wyjątek potwierdzający regułę (Faas, 2010, passim).

Znaczenie w podjęciu decyzji o wzięciu udziału w wyborach mają także dochody poszczególnych osób. Badania opinii publicznej prowadzone przez Instytut Allensbacha jednoznacznie wskazują, iż osoby z wyższymi dochodami częściej głosują niż te z niższymi. Według danych z 2009 r. stosunek ten wynosił 95 do 76\% (Petersen, Hierlemann, Vehrkamp, Wratil, 2013, s. 11).

Po szóste, nie bez znaczenia pozostają wspomniane już procesy demograficzne, przejawiające się odpływem istotnej części ludności ze wschodnich do zachodnich krajów związkowych. Poprzez zmianę miejsca zamieszkania po 1990 r. głównie przez ludzi młodych nowe kraje związkowe raczej bezpowrotnie utraciły osoby potencjalnie aktywne przez kolejne lata. Następstwa tego procesu nie wydają się możliwe do odbudowania w przewidywalnej przyszłości. Społeczeństwo wschodnich Niemiec na tle całego kraju szczególnie będzie dotknięte procesem starzenia się. Według prognoz Federalnego Urzędu Statystycznego do 2060 r. ludność RFN spadnie do 70,1 mln. W tym samym czasie na wschodzie ma mieszkać o 35\% mniej ludzi niż w 2011 r., już w 2030 r. o 13\% mniej. Liczba ludności w wieku między 20 a 65 lat ma spaść z obecnych 7,9 do $4 \mathrm{mln}$ (Bevölkerungsentwicklung..., 31.05.2015). W starzejącym się społeczeństwie we wschodnich krajach związkowych udział w wyborach będzie się zapewne zmniejszał. 


\section{PODSUMOWANIE}

Niższa frekwencja w wyborach do Bundestagu i parlamentów krajów związkowych jest na obszarze landów wschodnich faktem. Zjawisko to można wytłumaczyć, przywołując kilka czynników, których znaczenie jest zróżnicowane. 25 lat po zjednoczeniu Niemiec trudno mówić o pełnej unifikacji państwa, biorąc pod uwagę zachowania polityczne i wyborcze. Różnice nie są spowodowane jednak, jak w wielu innych państwach, rozbieżnościami regionalnymi, lecz stanowią pochodną okresu komunizmu, w którym NRD funkcjonowała przez 40 lat. W konsekwencji, jak już podkreślono, wzór zachowań politycznych, odniesienia do demokracji, instytucji demokratycznych, roli państwa upodabniają obszar wschodnich krajów związkowych RFN raczej do państw postkomunistycznych niż do zachodniej części Niemiec.

Z kolei udział w wyborach do Parlamentu Europejskiego w obu częściach Niemiec jest na zbliżonym poziomie, co należy tłumaczyć ich specyfiką, niezbyt wysokim poziomem wiedzy o działaniu instytucji UE, a co za tym idzie, zdecydowanie mniejszą chęcią uczestnictwa w tej elekcji.

Próbując kreślić scenariusz na przyszłość, trudno wskazać jakiekolwiek przesłanki, które mogłyby spowodować wzrost zainteresowania uczestnictwem w wyborach w tzw. nowych krajach związkowych RFN. Demograficzne następstwa zjednoczenia, brak większego zainteresowania polityką, większe niż na zachodzie Niemiec bezrobocie, de facto inne rozumienie demokracji powoduje, iż uczestnictwo w wyborach - zarówno na szczeblu ogólnopaństwowym, jak i krajów związkowych - pozostanie na wschodzie zapewne przez długie lata na innym poziomie niż na zachodzie Republiki Federalnej Niemiec.

\section{BiBLIOGRAFIA:}

Abold, R., Steinbrecher, M. (2007). „Wir wollen sein ein einzig Volk von Brüdern!”.

Die innere Einheit und das politische Verhalten der Deutschen. W: Rattinger, H., Gabriel, O.W., Falter, J.W. (red.), Der gesamtdeutsche Wähler. Stabilität und Wandel des Wählerverhaltens im wiedervereinigten Deutschland. Baden-Baden.

Bevölkerungsentwicklung und Altersstruktur (31.05.2015). Pobrane z: https://www. bpb.de/nachschlagen/zahlen-und-fakten/soziale-situation-in-deutschland/61541/ altersstruktur.

Dahl, R. (1995). Demokracja i jej krytycy. Kraków.

Deutschland 2014. 25 Jahre Friedliche Revolution und deutsche Einheit - öffentliche Vorstellung der Ergebnisse eines Forschungsprojekt. Sind wir ein Volk? (2015). Berlin: Bundesministerium für Wirtschaft und Energie. 
Deutschlands Atlas der Stärke, Focus, nr 22.

Dienel, C. (2004). Abwanderung aus Ostdeutschland - vom Wendephänomen zum langfristigen Trend?. W: Hufnagel, R., Simon, T. (red.), Problemfall Deutsche Einheit. Interdisziplinäre Betrachtungen zu gesamtdeutschen Fragestellungen. Wiesbaden.

Eisel, S. (2014). 25 Jahre nach dem Mauerfall. Die West-Ost-Wahlbeteiligungsschere. Pobrane z: http://www.kas.de/wf/doc/kas_39070-544-1-30.pdf?141008150145.

Ergebnisse früheren Bundestagswahlen. Stand: 5. Juni 2014. Informationen des Bundeswahlleiter (2014). Wiesbaden.

Ergebnisse früheren Landtagswahlen. Stand: 6.März 2014. Informationen des Bundeswahlleiter (2015). Wiesbaden.

Faas, T. (2010). Arbeitslosigkeit und Wahlverhalten. Direkte und indirekte Wirkungen auf Wahlbeteiligung und Parteipräferenzen in Ost - und Westdeutschland. Baden-Baden.

Gensicke, T., Olk, T., Reim, D., Schmithals, J., Dienel, H.-L. (2010). Entwicklung der Zivilgesellschaft in Ostdeutschland. Quantitative und qualitative Befunde. Berlin: Bundesministerium für Verkehr, Bau und Stadtentwicklung.

Hälfte der Deutschen hält Europawahl für unwichtig (2014). Pobrane z: http://www.zeit. de/politik/deutschland/2014-04/deutschlandtrend-umfrage-afd.

Wie zufrieden sind Sie im Allgemeinen mit der Demokratie in der Bundesrepublik und unserem ganzen politischen System? (2015). Pobrane z:

http://de.statista.com/statistik/daten/studie/260756/umfrage/umfrage-zur-zufriedenheit-in-ost-und-westdeutschland-mit-der-demokratie-und-dem-politischensystem/.

Einstellungen zur Demokratie (2015). Pobrane z: http://www.bpb.de/politik/grundfragen/deutsche-verhaeltnisse-eine-sozialkunde/138703/einstellungen-zur-demokratie.

Jammer-Ossis und Besserwessis existieren nur in Köpfen (2013). Pobrane z: http:// www.mz-web.de/panorama/meinungsumfrage-jammer-ossis-und-besserwessisexistieren-nur-in-koepfen,20642226,21746750.html.

Kleinhenz, T. (1995). Die Nichtwähler. Ursachen der sinkenden Wahlbeteiligung in Deutschland. Opladen.

Lipset, S. (1998). Homo politicus. Społeczne podstawy polityki. Warszawa.

Neller, K., Thaidigsmann, S.I. (2007). Sozialstrukturelle Eigenschaften, Wertorientierungen und ideologische Orientierungen der Stammwähler bei den Bundestagswahlen 1994 bis 2002. W: Rattinger, H., Gabriel, O.W., Falter, J.W. (red.), Der gesamtdeutsche Wähler. Stabilität und Wandel des Wählerverhaltens im wiedervereinigten Deutschland. Baden-Baden.

Neu, V. (2014). Europawahl in Deutschland am 25. Mai 2014. Wahlanalyse. Berlin.

Olk, T., Gensicke, T. (2013). Stand und Entwicklung des bürgerschaftlichen Engagements in Ostdeutschland. Quantitative und qualitative Befunde. Berlin: Bundesministerium des Innern.

Petersen, T., Hierlemann, D., Vehrkamp, R.B., Wratil, C. (2013). Gespaltene Demokratie. Politische Partizipation und Demokratiezufriedenheit vor der Bundestagswahl 2013. Gütersloh. 
Roland Rechtsreport 2015. Einstellung der Bevölkerung zum deutschen Rechtssystem und zur Mediation (2015). Köln: ROLAND Rechtsschutz-Versicherungs-AG, Institut für Demoskopie Allensbach.

Rose, R., Munro, N. (2009). Parties and elections in new European democraties. Colchester.

Roth, R. (2004). Jenseits der Blaupause - zum Transfer politischer Institutionen. W: Hufnagel, R., Simon, T. (red.), Problemfall Deutsche Einheit. Interdisziplinäre Betrachtungen zu gesamtdeutschen Fragestellungen. Wiesbaden.

Sartori, G. (1998). Teoria demokracji. Warszawa.

Simon, T. (2004). Von Divergenzen und Dissonanzen. Fragmentarische Einlassungen $\mathrm{zu}$ richtigen und falschen Diskursen ost - und westdeutscher Befindlichkeiten nach der Wende. W: Hufnagel, R., Simon, T. (red.), Problemfall Deutsche Einheit. Interdisziplinäre Betrachtungen zu gesamtdeutschen Fragestellungen. Wiesbaden.

Tag der Deutschen Einheit: Top 10 Ossi - und Wessi - Klischees (2013). Pobrane z: http:// www.presseportal.de/pm/107460/2562446.

Veen, H.-J. (1997). Innere Einheit - aber wo liegt sie? Eine Bestandaufnahme im siebten Jahr nach der Wiedervereinigung Deutschlands, Aus Politik und Zeitgeschichte, Bd. $40-41$.

Völkl, K. (2007). Nichtwahl - die Alternative für parteilich Ungebundene am Wahltag? W: Rattinger, H., Gabriel, O.W., Falter, J.W. (red.), Der gesamtdeutsche Wähler. Stabilität und Wandel des Wählerverhaltens im wiedervereinigten Deutschland. Baden-Baden.

Zawilska-Florczuk, M., Ciechanowicz, A. (2011). Jeden kraj, dwa społeczeństwa? Niemcy 20 lat po zjednoczeniu. Prace OSW, $n r 35$.

Zufriedenheit mit dem Funktionieren der Demokratie in Deutschland (2013). Pobrane z: http://www.bpb.de/nachschlagen/datenreport-2013/demokratie-und-politische-partizipation/174077/zufriedenheit-mit-der-demokratie, Bundeszentrale für politische Bildung. 